\title{
KEBIJAKAN PENYEDIA INFRASTRUKTUR IRIGASI PADA PROGRAM SWASEMBADA BERAS DI DESA TURA KECAMATAN PULAU MALAN KABUPATEN KATINGAN
}

\author{
Policy On Infrastructure Provider Of Irrigation In Swasembada Rice Program In The Village \\ Of Tura Malan Island In Katingan District
}

\section{Mambang* Pebry Agusthen}

Universitas Muhammadiyah Palangkaraya, Palangka Raya, Central Kalimantan, Indonesia

email:

mambang@umpalangkaraya.ac.id

\author{
Kata Kunci: \\ Kebijakan \\ Infrastruktur \\ Irigasi \\ Program \\ Swasembada Beras
}

\section{Keywords:}

Policy

Infrastructure

Irrigation

Program

Swasembada Rice

\section{Accepted \\ January 2019}

\section{Published}

April 2019

\begin{abstract}
Abstrak
Kabupaten Katingan sebagai salah satu kabupaten di Propinsi Kalimantan Tengah yang memiliki potensi lahan pertanian yang potensial sudah seharusnya menerapkan kebijakan penyedia infrastruktur irigasi pertanian di desa tura kecamatan pulau malan kabupaten katingan. Oleh karena itu, dalam penelitian ini peneliti ingin melihat faktor yang menyebabkan infrastruktur irigasi yang belum memadai. Jenis penelitian yang digunakan adalah penelitian kualitatif dengan teknik pengumpulan data wawancara, observasi, dokumentasi, tape recorder.

Hasil penelitian ini mengambarkan tentang infrastruktur saluran irigasi yang sarana dan prasarananya belum memadai. Saluran irigasi dalam mengairi lahan sawah pertanian petani sudah adanya saluran irigasi yang akan selalu menyalurkan sumber air. Permasalahan saluran irigasi tersebut saat ini yaitu belum adanya pintu air pada saluran irigasi di desa tura sehingga air sering keluar pada musim hujan sehingga dari saluran irigasi tersebut pada musim kemarau sering terjadi kekeringan air karena kekurangan ketersediaan air untuk sawah di desa tura, $\mathrm{Hal}$ ini menuai keluhan dari para petani yang bersangkutan karena sangat mempengaruhi hasil panen para petani, sarana dan prasarana sistem saluran irigasi ini kurang memadai sehingga hasil panen yang didapatkan hanya 2-3 pertahun sehingga panen setiap tahunya hanya untuk kebutuhan sehari-hari petani di desa tura, akan tetapi penyedia infrastruktur irigasi belum memadai di desa tura karena adanya pemotongan anggaran di dinas pertanian oleh pemerintah daerah untuk pembukaan akses jalan.
\end{abstract}

\begin{abstract}
Katingan Regency as one of the regencies in Central Kalimantan province that has potential agricultural land potentials should implement the policy of agricultural irrigation infrastructure in the village of Tura District Malan Island District Katingan. Therefore, in this research researchers want to see the factors that cause the irrigation infrastructure to be inadequate. The type of research used is qualitative research with the techniques of data collection interviews, observations, documentation, tape recorders.

The results of this study describe the infrastructure of irrigation channels, which means and infrastructures have not been adequate. Irrigation channels in irrigating farmland farmers have already had irrigation channels that will always channel the water source. The problem of irrigation channels today is the absence of water doors on the irrigation channels in the village of Tura so that water often comes out in the rainy season so that from the irrigation channels in the dry season, there is often drought in water due to lack Water availability for paddy fields in the village of Tura, it is reaping complaints from the farmers in question because it greatly affects the crops of the farmers, facilities and infrastructure of the irrigation tract system is insufficient so that the harvest obtained only 2-3 Per year until the harvest each day only for the daily needs of farmers in the village of Tura, but the provider of irrigation infrastructure has not been adequate in the village of Tura because of the budget cuts in the agricultural service by the local government for the opening Road access.
\end{abstract}

\section{PENDAHULUAN}

Pada hakekatnya pembangunan pertanian merupakan salah satu upaya yang dilakukan untuk meningkatkan taraf hidup masyarakat pedasaan melalui pemanfaatan sumberdaya pertanian. Pemerintah telah melaksanakan pembangunan infrastruktur bidang irigasi dengan perbaikan jaringan irigasi, termasuk jaringan irigasi kecil. Hal ini dilakukan dalam rangka 
memantapkan swasembada bahan pangan khususnya beras. Bangunan irigasi merupakan infrastruktur prasarana irigasi yang merupakan suatu kelengkapan jaringan irigasi teknis yang terletak pada jaringan irigasi dan berfungsi sebagai pengatur dan pengukur pemberian dan pembagian air irigasi ke areal pertanian baik secara langsung maupun tidak langsung.

Hampir seluruh wilayah sentral produksi beras di Indonesia menjalankan progam peningkatan produksi pangan strategi nasional melalui swasembada beras. Salah satunya adalah beras di Desa Tura Kecamatan Pulau Malan Kabupaten Katingan, Kebijakan Penyediaan infrastruktur irigasi di Desa Tura Kecamatan Pulau Malan Kabupaten Katingan dilakukan beberapa hal, yaitu sebagai berikut: I) Penyediaan infrastruktur irigasi di desa tura. 2) Meningkatkan teknik pengaturan air. 3) Meningkatkan pengelolaan padi untuk mencapai hasil yang masikmal tiap hektar dengan panen satu kali setahun.

Kondisi irigasi pada umumnya sangat memperhatikan fasilitasnya untuk saluran irigasi sehingga mampu mengaliri air dari areal irigasi ke lahan sawah, Kondisi sarana dan prasarana memegang peranan yang cukup penting dalam membantu aparatur untuk mencapai sasaran Dinas Pertanian, Pangan dan Perikanan Kabupaten Katingan, dinas pertanian kabupaten katingan bidang sarana dan prasarana mempunyai tugas yaitu menyediakan fasilitas infrastruktur irigasi pertanian, dengan adanya fasilitas sarana dan prasarana irigasi sebagai upaya dinas pertanian kabupaten katingan untuk meningkatkan usaha tani di desa tura kabupaten katingan.

Kebijakan infrastruktur irigasi di Desa Tura Kecamatan Pulau Malan Kabupaten Katingan diharapkan juga dapat memberikan manfaat yaitu untuk meningkatkan taraf hidup masyarakat petani serta meningkatnya ekonomi daerah setempat. Selain itu kebijakan infrastruktur irigasi dilakukan untuk peningkatan di bidang pangan terutama padi. Namun pada kenyataannya Masalah infrastruktur pertanian tentu menyangkut permasalahan tentang pembangunan infrastruktur irigasi yang sangat kurang memadai.

Sehingga hadirnnya penelitian ini adalah untuk mengetahui bagaimana kebijakan penyedia infrastruktur irigasi terhadap produktivitas sawah petani dan faktor-faktor apa saja yang mempengaruhi kebijakan penyedia infrastruktur irigasi terhadap produktivitas sawah petani di Desa tura kabupaten katingan.

\section{METODOLOGI}

Berkaitan dengan masalah yang dirumuskan diatas, maka jenis penelitian yang digunakan adalah kualitatif deskrptif. Penelitian kualitatif deskriptif yaitu penelitian yang dilakukan dengan maksud untuk menggambarkan dan atau melukiskan keadaan pada saat sekarang berdasarkan fakta-fakta yang tampak sebagaimana adanya. Dalam penelitian ini sepenuhnya melakukan analisis ke dalam jenis penelitian kualitatif deskriptif terhadap data-data yang dihimpun selama proses penelitian dari awal hingga pelaporan penelitian.

\section{HASIL DAN PEMBAHASAN}

Irigasi masa depan diharapkan dapat mendukung sepenuhnya untuk fungsi pertanian. Paling tidak, ada tiga fungsi utama yang terkait satu dengan lainnya yang memerlukan hubungan yang serasi. Pertama, fungsi yang menopang produksi pertanian pada umumnya termasuk pangan, peternakan, perikanan, perkebunan. Dengan perkataan lain suatu fungsi yang menunjang proses diversifikasi pertanian. Kedua, adalah fungsi konservasi Termasuk dalam fungsi ini adalah penyedia yang ada seperti infrastruktur irigasi persawahan. Ketiga, yang sangat penting dalam pengelolaan irigasi adalah asas keadilan dalam pembagian air. Banyak contoh irigasi yang dibangun masyarakat mewariskan rancang bangun pembangunan dan pengelolaan irigasi yang mencerminkan keadilan 
pembagian air yang dihubungkan dengan antara lain luasnya lahan yang diairi. Setiap hasil panen masyarakat pertanian desa tura kecamatan pulau malan kabupaten katingan rata-rata mencapai 2-3 ton sekali panen dalam pertahunya dari luas lahan pertanian desa tura $145 \mathrm{Ha}$. Hasil panen tersebut belum maksimal karena belum didukung oleh saluran irigasi yang baik, tidak ada hasil panen yang dapat mencapai 100\% karena pengaruh cuaca yang tidak menentu. Sehingga apabila infrastruktur irigasi belum memadai panen yang dihasilkan tidak optimal.

Saluran irigasi didefinisikan sebagai suatu cara pemberian air, baik secara alamiah ataupun buatan kepada tanah dengan tujuan untuk memberi kelembapan yang berguna bagi pertumbuhan tanaman. Dahulu para petani dalam mengairi sawah atau lahan pertanian mereka biasanya dengan cara membendung parit-parit penyaluran ke lahan mereka. Ada juga yang melakukan pengangkutan air menggunakan ember. Namun cara tersebut sangatlah melelahkan dan ditambah lagi apabila musim kemarau, maka cara tersebut tidak bisa dilakukan.

Pemanfaatan saluran irigasi terhadap kesejahteraan para petani sudah tidak lagi kesulitan dalam mengairi lahan pertanian mereka karena sudah adanya sistem irigasi yang akan selalu menyalurkan sumber air yang tak pernah berhenti. Sistem irigasi ini bisa dibuka tutup, sehingga kapan saja petani membutuhkan air untuk lahan pertanian mereka, tinggal membuka saluran air tersebut. Pemerintah sudah memberikan fasilitas irigasi dan membangun irigasi untuk dimanfaatkan oleh para petani.

Dari hasil observasi yang dilakukan penulis, saluran irigasi di desa tura kecamatan pulau malan kabupaten katingan tentunya sangat berguna $\mathrm{Hal}$ ini sebagaimana yang diungkapkan oleh penyuluh dinas pertanian desa tura bahwa:

"Dari tahun 2016-2018 pemerintah pusat kementerian pertanian sudah memberikan bantuan dari dana Bantuan sosial sebesar 100 juta. Dana Bantuan sosial tersebut diberikan langsung pada kelompok tani melalui rekening kelompok tani tersebut,akan tetapi melalui kelompok tani desa tura juga mendapatkan bantuan dari program optimasi lahan pertahunya sebesar 200 juta Rupiah, Dana tersebut langsung diberikan melalui rekening kelompok Tani desa tura ini berasal dari dana pusat kementerian pertanian untuk kebutuhan infrastruktur irigasi di desa tura, saya lihat petani-petani disini lebih terbantu, dengan adanya saluran irigasi ini adalah upaya dari pemmerintah untuk membantu petani kalau ingin mengalirkan air kesawah sawah mereka"

Sistem pintu air pada Saluran irigasi yang dimaksud sudah tidak berfungsi selama ini dari tahun 2016-20I8 belakangan ini. Untuk mengatasi masalah ini pemerintah pusat khususnya Kementerian desa mengambil beberapa kebijakan untuk mendukung petani di desa tura. Kebijakan yang dimaksud ditujukan Pemerintah menetapkan bantuan pemberian Bantuan tersebut berasal dari dana Kementerian desa. Bantuan tersebut untuk Pendanaan program irigasi oleh pemerintah pusat dilakukan dengan berbagai strategi. Adapun strategi pendanaan program irigasi yang ada di desa Tura saat ini yaitu dilakukan dengan melalui anggaran kementerian desa tersebut langsung diberikan kepada kelompok tani Desa Tura, seperti disebutkan pada wawancara pada ketua kelompok tani:

"Pemerintah pusat yaitu Kementerian desa memberikan bantuan untuk pertanian desa tura, Adapun bantuan tersebut berupa bantuan pompa air dan embung untuk membantu ketersediaan air untuk kebutuhan petani desa tura"

Adanya bantuan embung dan pompa air hanya cukup membantu mengailiiri air disekitar embung embung saja,air dari embung masih belum mencukupi untuk mencukupi kebutuhan sawah petani desa tura.

Adapun menjadi faktor penghambat pelaksanaan kebijakan infrastruktur irigasi dalam program swasembada beras di Desa Tura Kecamatan Pulau Malan Kabupaten Katingan yaitu

a. Dukungan Pemerintah Daerah 
Berdasarkan hasil penelitian ditemukan factor penghambat dalam pelaksanaan kebijakan penyedia infrastruktur irigasi pada program swasembada beras di Desa Tura yaitu kurangnya dukungan dari pemerintah daerah. Kebijakan Pemerintah daerah dalam hal ini Dinas Pertanian Kabupaten Katingan belum menyentuh kebutuhan dasar petani. Pemerintah Daerah terlalu terfokus pada pembukaan akses jalan, sehingga pada perencanaan program swasembada beras di Desa Tura tidak berjalan sesuai perencanaan.

\section{b. Pemotongan Anggaran}

Selain itu, menurut narasumber bahwa pemerintah Daerah Kabupaten Katingan melakukan pemotongan anggaran untuk program pertanian. Akibat dari Pemotongan anggaran untuk program juga terjadi pada pembukaan akses jalan kabupaten. Selain itu, pemerintah juga tidak serius dalam melaksanakan program irigasi sepenuhnya di Desa Tura pada khususnya, dan di Kabupaten Katingan pada umumnya. upaya yang telah dilakukan untuk mengatasi kendala-kendala yang ada dalam pelaksanaan kebijakan Penyedia infrastruktur irigasi pada program swasembada beras di Desa Tura Kecamatan Pulau Malan Kabupaten Katingan yaitu dengan mendorong petani untuk bergotong royong. Gotong royong yang dilakukan misalnya dengan membuat saluran irigasi untuk mengalirkan air dari sungai. Adapun faktor pendukung terhadap pelaksanaan kebijakan penyedia infrastruktur irigasi dalam program swasembada beras di Desa Tura Kecamatan Pulau Malan Kabupaten Katingan yaitu ketersediaan dana yang diperuntukkan mengoptimasi lahan dari dana bantuan social Kementerian Pertanian dan dari kementerian desa berupa embung dan pompa air, pada sistem pengaturan pintu pengairan sangat dibutuhkan untuk menjaga pertanian warga tetap dapat berproduksi. Berdasarkan hasil observasi yang dilakukan oleh penulis, Banyak lahan pertanian yang tidak teraliri oleh air karena fasilitas sistem irigasi saat ini kurang memadai.

\section{KESIMPULAN}

Bahwa Kebijakan Penyedia Infrastruktur Irigasi Pada Program Swasembada Beras Di Desa Tura Kecamatan Pulau Malan menunjukkan bahwa sarana dan prasarana pintu air belum ada disebabkan karena terbatasnya anggaran yang dimiliki oleh pemerintah. selain itu, pemerintah daerah juga belum sepenuhnya mendukung infrastruktur irigasi yang dibutuhkan oleh petani desa tura. Hal tersebut ditunjukkan dengan pengalihan anggaran yang dilakukan oleh pemerintah daerah untuk pembukaan akses jalan di daerah yang belum dapat dijangkau oleh pemerintahan kabupaten katingan. Pemerintah Pusat khususnya Kementerian Pertanian mengambil kebijakan untuk membantu petani dengan memberikan dukungan dana bantuan sosial sebesar 100 juta rupiah dan juga dari bantuan optimasi lahan 200 juta pertahunya, Pemerintah pusat juga memberikan bantuan melalui Kementerian Desa juga memberikan bantuan pompa air dan embung untuk membantu ketersediaan air di desa tura.

Faktor Penghambat Kebijakan Penyedia Infrastruktur Irigasi Di Desa Tura yaitu: Kurangnya Dukungan pemerintah Daerah, Pemerintah Daerah kurang memperhatikan penyiapan infrastruktur irigasi bagi petani. Pemerintah terlalu terfokus pada pembukaan akses jalan, adanya Pemotongan anggaran tersebut untuk pembuatan akses jalan yang daerahdaerah masih belum dapat dijangkau. sehingga program swasembada beras di Desa Tura tidak sesuai perencanaan. Dalam hal ini Pemerintah Daerah Kabupaten Katingan melakukan pemotongan anggaran pada dinas pertanian untuk kebutuhan akses jalan sehingga pelaksanaan kebijakan penyedia infrastruktur irigasi pada program swasembada beras di Desa Tura belum belum direalisasikan. 


\section{REFERENSI}

Direktorat Irigasi dan Rawa Direktorat Jenderal Sumber Daya Air. 2006. Pedoman Operasi Irigasi. Departemen Pekerjaan Umum. Jakarta.

Huraerah, Abu. 2008. Pengorganisasian dan Pengembangan Masyarakat, Model dan Strategi Pembangunan, Bandung : Humaniora.

Moleong, J. Lexy. 2012. Metodologi Penelitian Kualitatif. Bandung: PT Remaja. Rosdakarya.

Robert, J., Syarief, R. 2010. Tata Ruang Air. Penerbit Andi. Yogyakarta.

Rukminto, Adi Isbandi. 2007. Perencanaan Partisipatoris Berbasis Aset Komunitas : Dari. Pemikiran Menuju Penerapan. Depok: FISIP UI Press.

Soenarno. 2004. Tiga Program Pokok Untuk Ketahanan Pangan. Media Informasi Sumber Daya Air Departemen Pekerjaan Umum. Jakarta.

Suharto, Edi. 2004. Pendekatan Pekerjaan Sosial dalam Pemberdayaan Masyarakat Miskin: Konsep, Indikator dan Strategi, Malang.

Sujianto. 2008. Implementasi Kebijakan Publik Konsep, Teori dan Praktik. Pekanbaru : Alaf Riau

Surjadi. 2009. Pengembangan Kinerja Pelayanan Publik. Reflika Aditama.Bandung.

Surmayadi, Nyoman.I. 2005. Efeketifitas Implementasi Kebijakan Otonomi Daerah. Jakarta: Citra Utama

Suyanto, Chokkalingam, U., Wibowo, P. 2003. Kebakaran Dilahan Rawa/Gambut di Sumatera:Masalah dan Solosi. Cifor. Palembang.

Sunyoto, Usman. 2004. Pembangunan dan Pemberdayaan Masyarakat, Yogyakarta, Pustaka Pelajar.

Syaukani, dkk. 2004. Otonomi Daerah dalam Negara Kesatuan. Yogyakarta: Pustaka Pelajar

Wahab, Solichin Abdul. 2005. Analisis Kebijakasanaan dari Formulasi ke Implementasi Kebijaksanaan Negara, Jakarta : Bumi Aksara
Waluyo.2007.Manajemen Publik (Konsep, Aplikasi dan Implementasinya Dalam Pelaksanaan Otonomi Daerah. Mandar Maju. Bandung.

\section{Perundang-undangan}

UU Nomor 22 Tahun 1999 tentang Pemerintahan Daerah, UU Nomor 32 Tahun 2004 tentang Pemerintah Daerah.

UU Nomor 12 Tahun 2008 tentang Perubahan Kedua Atas Undang-Undang Republik Indonesia Nomor 32 Tahun 2004 tentang Pemerintahan Daerah.

UU Nomor 23 tahun 2014 tentang Otonomi Daerah. Peraturan Pemerintah Republik Indonesia No. 20. 2006 